\title{
Community Contacts: Being Prepared for a Disaster ${ }^{1}$
}

\author{
Linda B.Bobroff ${ }^{2}$
}

\section{Community Contacts: Being Prepared for a Disaster}

When a disaster strikes, it's too late to get ready. It's important to prepare for a disaster before an emergency occurs. Along with the information provided in this series, the agencies listed can help you be well prepared to handle just about any emergency. The time to get ready is NOW, so call the agencies for information or, if you have Internet access, look at the websites and print out what you need. Put together your disaster kit and your disaster plan BEFORE you need it.

\section{NATIONWIDE RESOURCES}

\section{Federal Emergency Management Agency} (FEMA): Helps you plan for and recover from any type of disaster.

(202) 566-1600

Http://www.fema.gov

American Red Cross: Provides information on planning for disasters, as well as providing assistance after a disaster occurs.

(202) 303-4498

Local number:

Http://www.redcross.org

READY.GOV: Website set up by U.S. Dept. of Homeland Security to help people plan for emergencies related to terrorism. Http://www.ready.gov

\section{FLORIDA RESOURCES}

\section{Florida Dept. of Law Enforcement:}

Coordinates domestic security through regional task forces.

\section{Http://fdle.state.fl.us/osi/}

\author{
Florida Division of Emergency \\ Management: Provides a wealth of \\ information to help you prepare for any \\ emergency. Find out about Community \\ emergency Response Teams.
}

(850) 413-9969

Http://www.floridadisaster.org/

MyFlorida Website: Links to information about preparing for all types of disasters, preventing disasters, critical contacts, and current news.

Http://myflorida.com/portal/Floridian

Florida Citizen Corps: State partner of USA Freedom Corps. Organizes volunteers who help build safer, more resilient communities. (850) 413-9957

Email: citizencorps@dca.state.fl.us Http://www.floridadisaster.org/director_off ice/citizen_corps/

1. This document is FCS9190, one of a series of the Department of Family, Youth and Community Sciences, Florida Cooperative Extension Service, IFAS, University of Florida, Gainesville FL 32611: First published: May 2003. Reviewed: May 2003. Reviewed by: Elizabeth Bolton, Ph.D., professor, Department of Family, Youth and Community Sciences, Gainesville, FL 32611. Please visit the EDIS Web site at http://edis.ifas.ufl.edu

2. Linda B. Bobroff, Ph.D., associate professor, Department of Family, Youth and Community Sciences, University of Florida, Gainesville FL 32611. 